\title{
Um objeto em vias de extinção. 0 resgate teórico- etnográfico da cultura e do trajeto sócio-histórico do operariado agrícola alentejano (1926-1974)
}

João Valente Aguiar*

Resumo: Será possível a uma perspectiva sociológica resgatar, de forma analítica e empírica, um objeto de estudo quase desaparecido? Tentamos responder a esse desafio tendo como base uma aproximação etnográfica a um objeto de estudo relativamente desconhecido: os trabalhadores assalariados rurais do Alentejo. Agregando dados qualitativos assentes na análise de conteúdo de poemas e canções populares da região e em testemunhos de antigos operários agrícolas, (re)construiu-se uma trajetória das mobilizações históricas no Alentejo, durante a ditadura do Estado Novo (1926-1974). O propósito central passou a ser dar conta da interação entre a esfera cultural, atendendo seus dispositivos simbólicos e ideológicos, e o processo de organização e mobilização da referida classe social.

Palavras-chave: cultura popular; classe trabalhadora; etnografia.

An object in erosion. The recollection of the culture and the socio-historical path of the rural working class in Alentejo (1926-1974)

Abstract: Is there any chance to an almost disappeared social group be analitical and empirically rescued by a sociological perspective? We tried to answer to this challenge based on an etnographic approach to a relatively unknown object: the rural labour workers in Alentejo. Gathering qualitative data, based on content analysis of popular poems and popular songs of that region and on the testimonies of former rural workers, we build a reconstrutive path of historical mobilizations in Alentejo during the dictatorship of Estado Novo (1926-1974). Our purpose was to cover the interaction between cultural sphere, attending to its ideological and symbolic devices, and the process of organization and mobilization of the supramentioned social class.

Keywords: popular culture; working class; etnography.

\footnotetext{
* Doutorando em Sociologia pela Faculdade de Letras do Porto, Portugal.
} 


\section{INTRODUÇÃO}

Michael Burawoy afirmou num ensaio que já se tornou clássico, "porque os operários trabalham tão duramente?" (Burawoy, 1982, p. xi). Para o autor, a construção do consentimento constitui o foco central da sua análise. Num direcionamento claramente oposto, o nosso ponto de partida para a investigaçáo aqui exposta poder-se-ia expressar na questão: "por que se mobilizam os trabalhadores?". Perante todas as "evidências", ao longo dos últimos I50 anos, vários contingentes de indivíduos e grupos de indivíduos pertencentes à classe trabalhadora organizaram-se coletivamente e romperam com o manto de inércia que as estruturas sociais do capitalismo instilam nos comportamentos dos agentes sociais. Independentemente do resultado final dos seus empreendimentos, sublinhe-se o fato de as classes dominadas terem, em determinados contextos espaço-temporais e por intermédio da sua mobilização coletiva, irrompido na cena social e política, cortando amarras a décadas de vida anônima e anódina.

Com efeito, a nossa investigaçáo surgiu orientada para a prossecução de um objetivo central: de que forma a cultura popular produzida pelo operariado agrícola alentejano contribuiu para a mobilização social e política dessa classe social durante o Estado Novo? Nesse sentido, interessounos interrogar o social a partir de uma perspectiva sociológica que incluísse uma veia temporal. O nosso propósito de investigaçáo aqui exposto versou a integraçáo de conceitos que remontam a dimensóes predominantemente simbólicas - a cultura popular ${ }^{\mathrm{I}}$ - com conceitos que substantivem uma aproximaçáo mais histórica - a formaçáo da classe trabalhadora ${ }^{2}$. No fundo, dois eixos conceptuais que pretenderam captar não apenas um fragmento da cultura popular alentejana ou o trajeto sócio-histórico dos assalariados agrícolas daquela região, mas a sua inter-relação.

\section{O MAPEAMENTO METODOLÓGICO DA PESQUISA DE TERRENO}

\footnotetext{
I Definimos cultura popular a partir das seguintes proposiçóes: a) geraçáo e produçáo de cultura, isto é, de objetos materiais, mas também de sentidos, representaçóes, valores, redes de sociabilidade e interaçóes individuais e grupais pelos trabalhadores; b) sua presença na sociedade é variável, consoante o grau de contradiçôes e de correlação de forças das classes dominadas no campo mais vasto das classes sociais; c) é igualmente variável no espaço que ocupa no campo cultural, de acordo com a maior ou menor penetração da cultura e das ideologias de outras classes, bem como do intercâmbio e das influências estéticas que se estabelecem entre si.

2 Edward Thompson definiu a formação da classe trabalhadora como um conjunto de dinâmicas intrínsecas à classe social, "um processo activo que deve tanto à agência como ao condicionamento" (THOMPSON, I99I, p. 8). Basicamente, Thompson trabalha a relação dialética entre capacidade - historicamente e contextualmente variável - de organização própria e por iniciativa da classe e os freios ao desenvolvimento da auto-organizaçáo da classe, colocados pelas estruturas sociais (Estado, mercado, ideologias) e pela classe dominante. Assim, a classe não é em Thompson uma estrutura, mas um processo, melhor dizendo, um conjunto articulado de práticas coletivas; conjunto de práticas dotado de historicidade. Isto é, uma mesma classe social é passível de adotar diferentes comportamentos e açôes coletivas ao longo de sua existência de referir que cada classe tem sempre uma margem mínima e máxima para a produçáo e efetivação de práticas próprias - culturais e políticas - e que estas podem fornecer ou receber elementos de práticas de outras classes. Por conseguinte, a "classe entende-se como um fenómeno histórico unificando um número de eventos aparentemente desconexos, tanto na matéria bruta da experiência como na consciência. Enfatize-se que este é um fenómeno histórico. Náo vejo a classe como uma 'estrutura', nem mesmo como uma 'categoria', mas como algo que acontece na realidade (e que pode ser mostrado como aconteceu de fato) das relaçóes humanas” (Ibidem).
} 
Para a fecundidade de um trabalho de investigaçáo sociológica, afirma-se pertinente "conjugar e fazer coexistir a linguagem da experiência, de estar e pensar no trabalho de campo, com a linguagem da teoria, que permite objetivar e racionalizar o que ocorreu" (CARIA, 2002, p. IO). Como mediador das duas linguagens - empírica e teórica -, a metodologia protagoniza uma "construçáo estratégica" (CARIA, 2002, p. 9), uma ponte entre os dois tabuleiros.

Segundo Madureira Pinto e João Ferreira de Almeida (Pinto; Almeida, 1995, p. I24), é inquestionável a existência de uma reciprocidade entre teoria e empiria:

sendo, pois, a investigação empírica largamente tributária da teoria, já se vê que a progressão na produção de conhecimentos concretos se terá de fazer, em larga medida, na dependência e do ritmo e natureza da análise propriamente teórica. O que náo significa que a pesquisa empírica esteja impedida de exercer, ela própria, uma influência marcante sobre a teoria que comanda os seus momentos fundamentais.

No fundo, para um mergulho consequente nas profundezas do real-social, é absolutamente necessário estabelecer e definir uma "estratégia integrada de pesquisa" (COSTA, 200I, p. I29) que “organize criticamente as práticas de investigação" (Pinto; AlmeidA, I995, p. 80).

Em nosso trabalho de investigaçáo - que poderíamos incluir no rol de estudos centrados em uma pesquisa de terreno com características etnográficas -, procurou-se cumprir a sugestáo de Firmino da Costa (200I, p. I29): a necessidade de "uma presença prolongada do investigador nos contextos sociais em estudo e contacto directo com as pessoas e as situaçóes".

Nesse sentido, uma presença relativamente longa no terreno (cerca de quase três meses, em um total de dez) veio acompanhada de um mapeamento metodológico que orientasse e organizasse, nunca rigidamente, o trabalho de campo. No fundo, a assunçáo e enunciaçáo de princípios metodológicos que se coadunassem com os objetivos da investigaçáo andaram de braços dados com uma "atitude sociológica" que "foi sempre a de expectativa, a de abertura preponderantemente receptiva” (PAIS, 2000, p. 13).

Por conseguinte, nossa abordagem de cariz etnográfico - mais no que toca ao processo de recolha e tratamento da informação do que propriamente na construção teórica prévia - procurou corresponder a uma

análise centrada na construçáo social do quotidiano, partilhado em rotinas de acçáo e negociado em consensos e conflitos sobre regras de significação e de uso legítimo dos recursos, e não em qualquer visão "essencialista" e/ou exótica da cultura local (CARIA, 2002, p. I4).

O mesmo consiste em afirmar que o processo de organizaçáo da investigaçáo não se baseou na construção de um objeto de estudo singularíssimo ou portador de qualquer missão histórica definida de antemão, mas que as "conclusóes" alcançadas decorrem da dinâmica descortinada 
no decurso do próprio processo de investigação. Em termos práticos, a articulação entre teoria geral de partida e mergulho etnográfico no terreno náo funcionou somente como um exercício de ligação entre os níveis macro e micro da realidade social. Nos marcos da grounded-theory, o método etnográfico revelou-se fundamental como alavanca estratégica capaz de respaldar os dados empíricos em um quadro teórico final, o que Seale (2000, p. 109) define como "generalização teórica”.

Consequentemente, reforça-se a relevância dos procedimentos etnográficos de pesquisa para, por um lado, colher os elementos de ordem subjetiva e simbólica existentes no solo da realidade social e, por outro lado, poder enquadrá-los em termos mais genéricos, em um quadro teórico mais abstrato.

Recorremos, portanto, à etnografia em um âmbito inverso ao sentido singularizante dado por Geertz aos estudos qualitativos de tipo etnográfico. Para esse autor, "qualquer proposta de teoria geral a respeito de qualquer coisa social soa cada vez mais vazia" (GEERTZ, I999, p. IO), reforçando a ideia de que o pensamento sociológico é sempre local.

Não se contesta a contextualização imanente à produção do conhecimento em Ciências Sociais nem se busca, muito menos, a construçáo de uma teoria acabada e final sobre uma dimensão qualquer do real-social. $\mathrm{Na}$ verdade, a construção de princípios teóricos gerais conceitos, conjuntos de conceitos e hipóteses - não é, de nosso ponto de vista, um exercício antagônico com o municiar de procedimentos qualitativos e etnográficos.

Ao mesmo tempo, náo procuramos generalizar precipitadamente conclusóes de um caso específico vivido pelo operariado agrícola alentejano, entre 1926 e 1974, mas, contrariamente, empreender uma tentativa de discernir até que ponto a originalidade de cada acontecimento social comporta traços estruturantes e passíveis de ocorrer (em termos de possibilidades/probabilidades históricas) em outros contextos.

Para a robustez do mapa metodológico de orientação da pesquisa empírica, abraçou-se uma postura de constante reflexividade sobre as relaçóes sociais de observação, ou, nas palavras de Telmo Caria (2002, p. II): "as condições sociais da observaçáo/inquirição do social”.

Considerando que a produçáo teórica é necessariamente influenciada pela perspectiva adotada, a problematização teórica e metodológica da localizaçáo do investigador em um determinado ponto de vista (analítico e no terreno) é impreterível para a solidez do estudo sociológico. Ao investigador no terreno não basta apenas a reflexividade, de forma a controlar seus procedimentos e a orientar sua trajetória de investigaçáo. Importa, igualmente, que, entre outros domínios e competências, o investigador seja capaz de, mantendo o devido distanciamento metodológico, adequar sua linguagem (verbal e náo verbal) ao público em estudo. Daí que a informalidade,

que supóe um processo de ajustamento recíproco, permita que, aos efeitos inerentes à presença do investigador no terreno e à interacçáo deste com as pessoas, não se venha juntar uma maior rigidificaçáo dos papéis recíprocos do observador e do observado e 
uma maior rigidificação das categorias que organizam o processo de interacção verbal (Costa, 200I, p. I38).

Por essa via, o investigador não apenas se aproxima mais estreitamente de seu objeto empírico de estudo como, simultaneamente, pode "experienciar", sob condiçôes de profundo controle e vigilância epistemológica, ética e metodológica, determinadas (micro)vivências dos agentes sociais.

Assim, a presença prolongada no terreno, a multiplicidade de dimensóes analisadas do real e o confronto sistemático entre seu habitus e o universo dos habitus dos agentes estudados funcionam como meios que permitem conferir objetividade à investigaçáo, ou seja, recolha e tratamento de dados levados a cabo com instrumentos técnicos e metodológicos controlados de forma sistemática, tendo em mente o princípio basilar do "conhecimento das condiçôes de conhecimento" (Bourdieu, I980, p. 7).

Tendo optado por um estudo orientado para a captação da subjetividade operária, é natural que a escolha $\mathrm{da}(\mathrm{s})$ metodologia(s) procure cumprir tal desígnio. Nesse sentido, a metodologia qualitativa surgiu como a mais adequada para indagar sobre os significados e as percepçóes que os trabalhadores extraem e manifestam a partir de seu envolvimento com as condiçóes culturais (e extraculturais) de existência. Na prática, a maior preponderância da metodologia qualitativa prendeu-se com o fato de que:

ao intentarmos a reconstruçáo das culturas operárias, somos obrigados a prestar a devida atençâo aos modos de ver e aos modos de ser, sendo que as investigaçōes sociológicas quantitativistas baseadas em questionários fechados e na compilação de estatísticas são de importante mas limitada valia na reconstrução das estruturas de ver e sentir (KIRK, 2004, p. 5I).

Por conseguinte, o estabelecimento de uma metodologia de maior pendor qualitativo assumiu importância capital em nosso trabalho. Acentue-se a necessidade de integrar técnicas robustas - sobretudo, mas nunca apenas, técnicas que apelem para a autoexpressividade do sujeito (entrevistas não estruturadas e semiestruturadas; análise de conteúdo; observação direta; histórias de vida; fotografia social) -, em uma abordagem plural e intensiva delas. Tal propósito enquadrou a utilização de técnicas como a análise de conteúdo, histórias de vida, entrevistas semiestruturadas e não estruturadas, bem como a recolha e análise documental e o uso da fotografia social. Cada uma das técnicas procurou registar diferentes facetas do polígono social complexo que abarca os fenômenos relacionados com a formaçáo da classe trabalhadora e o papel da subjetividade e da cultura nesse processo.

Por tudo o que tem sido enunciado, é razoável admitir que esse trabalho metodológico do pesquisador qualitativo se assemelha a um bricoleur, a uma "construção emergente" (Denzin, I998, p. 3). A capacidade que a metodologia qualitativa tem para resgatar "os momentos e os 
sentidos dos indivíduos" (DENZIN, I998, p. 3) inclui uma combinação de dimensões com diferente estatuto gnoseológico.

Por um lado, temos, assim, a "voz" e a vivência do agente social como ele próprio a interpreta. Por outro lado, ocorre um exercício interpretativo do investigador, que, sem adulterar a subjetividade do sujeito, produz uma reflexão compreensiva sobre a reflexão atuante do agente social. Tal fato implica apreender a investigação qualitativa como um local de "múltiplos métodos e práticas de pesquisa" ((DENZIN, I998, p. 5). Denota-se, portanto, um enraizamento das técnicas de tonalidade interpretativa em um trajeto de investigação bidirecional entre teoria e empiria.

Esse movimento entre empiria e teoria convoca uma comunicação mais estreita entre processo real e processo de conhecimento. Destaque-se que isso não significa necessariamente a subversão completa da função de comando da teoria. Pelo contrário, trata-se de recusar as visóes que tendem a fechar a teoria em si mesma, reduzindo a problematização sociológica a uma especulação escolástica. Na verdade, a teoria continua a ser o ponto de chegada de uma investigação sociológica qualquer. Ou seja, o maior vaivém entre teoria e empiria não é um fim, mas atua e interage como mola propulsionadora do incremento da qualidade heurística e como afinamento dos quadros teóricos existentes.

É neste âmbito que a supramencionada grounded theory aponta. Ela consiste no processo de "gerar teoria e a descoberta sistemática de teoria a partir dos dados recolhidos na investigaçáo social" (GLASER; STRAuss, I997, p. 3). Em outras palavras, trata-se de considerar que a adequação da teoria não está "divorciada do processo em que foi gerada” (Glaser; STrauss, 1997, p. 5).

Nesse sentido, o investigador etnográfico não só se municia com um quadro teórico de partida, mas também, com o decurso da investigaçáo, os dados empíricos permitem forjar novos eixos de fundamentaçáo teórica, complementando e refinando a análise.

De fato, com um arsenal teórico de partida - ancorado nos conceitos de cultura popular e de formação da classe trabalhadora (ver notas i e 2) -, procurou-se complementar a análise por meio da canalizaçáo de elementos e dados recolhidos no terreno, em um confronto entre elaboração teórica e indagação empírica que procurou ser fecundo.

\section{UMA PRIMEIRA FACETA DA CULTURA POPULAR ALENTEJANA: A POÉTICA CANTADA}

Abordaremos a seguir três eixos nucleares de nosso trabalho empírico. Nesse primeiro eixo consagramos espaço ao estudo da cançáo (e poesia) popular em si mesma(s), antes de se enunciarem as principais vias de acesso à substância daquela poética (cantada).

Em termos genéricos, abordou-se o canto alentejano como modalidade mais acessível para uma mais frutífera indagaçáo empírica. No fundo, a poética cantada ${ }^{3}$ alentejana reporta-se a uma

\footnotetext{
3 Designamos o canto alentejano, como é vulgarmente denominado, de poética cantada, no sentido em que nessa prática cultural se entrecruzam duas técnicas artísticas principais: a poesia popular e sua correlativa musicalização por via da interpretação vocal.
} 
das mais fecundas performances artísticas do operariado agrícola da região, desde há centenas de anos.

$\mathrm{Na}$ sequência da pesquisa de terreno, procurou-se fundar uma breve tipologia temática/ semântica dos elementos mais presentes na poética cantada alentejana. Deu-se conta de um breve exercício comparativo do trajeto sócio-histórico do operariado alentejano e sua subjetividade de classe. Relativamente a este último tópico é fácil avançar com a ideia de que esta se caracterizou por ser uma subjetividade de resistência, de oposição aos dominantes, um polígono social substantivamente coeso e agregado coletivamente com finas e afiadas arestas para desferir sobre o peso do poder das classes dominantes e suas instituiçôes (o Estado) e grupos sociais (os feitores e capatazes) adstritos. Essa subjetividade operária encontra-se espelhada em uma de suas dimensóes mais relevantes: a poética cantada.

No seio desta última resenham-se os seguintes tópicos temáticos:

a) A poesia propriamente dita. Dimensão autorreflexiva da poesia popular sobre si mesma. Entre outros domínios, esse é certamente um dos que mais contribui para aferir sobre o desenvolvimento estético do canto popular alentejano como uma criação artística de pleno direito.

b) A natureza. Os traços de humanização da natureza encontrados na poética cantada popular decorrem náo de uma simples atribuição de características humanas a aspectos ou facetas do universo natural. De fato, existe certa metaforizaçáo, conotando diferentes domínios da natureza com distintas simbologias humanas.

c) $O$ amor. Encontram-se nos cantos populares alentejanos tonalidades típicas de poemas de amor: a ausência do outro, a busca do outro, a saudade do outro, os desencontros, o corpo como materializaçáo do amor, mas também como limite terreno desse sentimento humano.

d) A reflexão sobre a condição humana. As dificuldades de sobrevivência, o desemprego por grandes períodos e o corte/dessacralização do viver religioso desaguaram em reflexôes sobre a condição humana, que, em determinadas composiçôes poéticas, aproxima-se de certo niilismo. O canto religioso é marcante, sobretudo, em períodos de festas religiosas, funcionando como translaçôes temporais de tradições religiosas ancestrais - cantar aos Reis e no Natal - e que assumiam mais dinâmicas de ritualização nas festividades e menos uma consagração religiosa de um balizar da vida quotidiana terrena em uma linguagem transcendental. Todavia, outra abordagem persiste nos trabalhadores alentejanos não religiosos - se não a maioria, pelo menos, uma importante fatia da populaçáo - o anticlericalismo ou a própria politização de Jesus Cristo, incorporando-o em seu ideário político:

Entre Jesus e Lenine

há um laço que os une

há um braço que os define 
Lenine a sábia centelha

pregou a paz e o amor

também Jesus Cristo

pregou tal e qual o mesmo

(Lima; Correia, 2006, p. 54).

Essa condição existencial leva o trabalhador rural a centrar a reflexão sobre sua vida em termos muito práticos: sobre a natureza, sobre a paisagem e, o que é mais importante, sobre si, seu corpo e seus semelhantes e como estes se relacionam com o mundo terreno que veem em seu redor, isto é, com a propriedade.

e) Terra ou lugar? "O "apego à terra" tende a sintomaticamente ser atribuído a populações rurais. No fundo, as teses da gemenschaft versus geselchaft, ou seja, da comunidade versus a sociedade ou da tradição versus a modernidade fundam uma aporia que, o mais das vezes, obscurece o real conteúdo de certos expedientes dos estilos de vida das populaçóes situadas fora dos grandes centros urbanos. No Alentejo, nomeadamente no que se pôde recolher das cançóes populares, esse sentimento de "apego à terra" é mais uma ligação ao lugar do que propriamente à posse da terra, como é mais característico no campesinato nortenho (Pinto, I985; AlmeIDA, I999; Silva, I998). De fato, mais do que um sentimento de propriedade, o operariado agrícola alentejano identifica-se, em um primeiro momento, com o lugar onde habita e onde forjou sua subjetividade. Temos, assim, uma forte presença da identidade local no corpo textual das composiçôes populares alentejanas. Isto é, o modo de ser do operário rural alentejano fundamenta uma visão de identificação com o lugar, mas não com a propriedade.

f) A condição do "pobre". Um dos fenômenos sociais tristemente mais identificadores do Alentejo durante séculos foi a pobreza e mesmo a miséria em que viviam milhares e milhares de famílias trabalhadoras. A profusão de composiçóes poéticas (cantadas) descrevendo as condiçóes penosas do operariado agrícola é imensa:

Vêem-se corpos humanos

Suportando mil enganos

Da sociedade que os intruja

[...]

Semeando com fome e frio

Andam os corpos seminus

Acompanhando essa cruz

[...]

Farrapos da humanidade

Abandonados da sorte 


\section{Estendendo os braços à morte \\ À mercê da caridade \\ $\mathrm{Na}$ alta sociedade \\ Gastam-se notas aos maços \\ Vindo de ricos terraços \\ Ouvem-se risos de fera \\ Lá está o pobre à espera \\ Dos meios tostóes dos ricaços \\ (VVAA, 200I, p. 7I-72).}

O sentimento de injustiça em relação à miséria existente durante o Estado Novo nos campos alentejanos e o sentimento de compaixáo com os trabalhadores pobres e mendigos assomam como dois dínamos da elevação da consciência social do operariado agrícola alentejano, fato bem espelhado em sua poética cantada.

Registe-se ainda a percepção da situação de pobreza como um fenômeno não atribuído a fatores naturais ou inelutáveis, mas à situação amplamente favorecida do que chamavam de "ricaços": os latifundiários e os senhores da terra.

g) A condição operária. Um elemento identificativo da cultura operária e popular alentejana era, inequivocamente, o trabalho assalariado. Desde as simples mençóes à vida de trabalho -

Mondadeira alentejana,

Lenço de todas as cores,

Vai mondando, vai cantando

Cantigas aos seus amores

(VvaA, 1994, p. 67).

- até a centralidade do trabalho como marco de estruturação da vida quotidiana e na própria constituição das "regras do jogo no mercado matrimonial" (AlmeIdA, 1999, p. 258):

\section{Ceifeira!}

Ceifeira, linda ceifeira!

Eu hei-de,

Eu hei-de casar contigo!

Lá nos cam...

Lá nos campos, secos campos,

Lá nos campos, secos campos, à calma a ceifar o trigo

(VVAA, I994, p. 7I). 
A consciência do núcleo estruturante e nevrálgico do trabalho assalariado é por demais evidente em dois poemas:

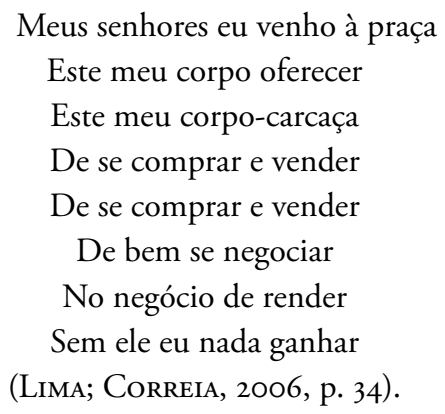

\section{MOTE}

Ó trabalhador rural

Vem estudar esta lição

Se és tu que vives mais mal

Quando tudo tens na máo.

Vem cá pobre criatura

Da vida precária e cega

Que lutas com tanta miséria

E produzes tanta fartura

A tua tarefa é a mais dura

O teu sofrer é sem igual

O teu braço o principal

Que fornece o suave pão

Do qual não tens um quinhão

Ó trabalhador rural

(NAVARRo, 2002, p. 76).

Aqui denota-se uma aguda ilustração do cerne e dos efeitos do trabalho assalariado, isto é, da venda da força de trabalho como elemento estruturante das relaçóes sociais de produção vigentes naquele contexto.

h) O confronto (de classe) com o poder. Dos dois últimos eixos temáticos, com maior incidência causal, mas também pela articulaçáo de todos os anteriores, o confronto da classe operária alentejana com a classe dominante nos campos e suas instituiçóes representativas iria ser uma realidade. 
Em primeiro lugar, destaca-se o desaguar de múltiplas tendências secundárias, mas nem por isso desprezíveis. O cruzamento entre a existência de um saber fazer performativo próprio - a poética cantada popular; a ligação à natureza e a pulsão de materializar um viver social que permitisse uma vivência frutífera e harmoniosa entre produtores e o mundo natural, bem como a humanização dos elementos naturais; a profusáo de sentimentos de amor e de generosidade com o próximo; e o sentido existencial oscilante entre um pessimismo e uma consciência da vida humana operária como despojada a não ser de si mesma e de seu lugar biológico - o corpo -, a par de uma religiosidade incipiente e, quando existente, meramente ritualista - marcaria, em seu todo, um modelo de variáveis essenciais para a consolidação de uma identidade operária muito própria.

Por outro lado, esse cruzamento que se designa secundário interliga-se com o cruzamento fulcral entre, por um lado, o sentimento de injustiça perante as condiçóes de vida concretas do operariado e, por outro, a compreensáo de sua condição de trabalhadores assalariados e com o que seria, nessa relação social fundamental que residiria, a raiz principal de seu modo de viver, construindo uma forte identidade e identificação coletiva da classe operária agrícola alentejana.

Nesse sentido, a criaçáo de um mundo cultural muito próprio de representaçóes sociais, mas também de sociabilidades culturais moldaria a revivescência de um cenário social polarizado em termos de posicionamento social (a disparidade dos lugares de classe entre os agrários e o operariado da região), bem como em termos de açáo social. Diz-se polarizado em termos de açáo social pela paulatina e gradual construção do operariado agrícola alentejano como sujeito social coletivo, com referenciais simbólicos e com práticas de classe independentes; logo, com interesses coletivos bem definidos e contrastantes com os da burguesia agrária.

Portanto, o primeiro nível da constituição de um universo cultural operário passa pela assunção das diferenças entre trabalhadores e patrôes, como agentes sociais distintos, mas intimamente relacionados em seus propósitos políticos, sociais e econômicos:

Há lobos sem ser na serra

Ainda não sabia

Debaixo do arvoredo

Trabalho de noite e de dia.

O rico é como o sapo

Só tem barriga e pança

O pobre é como a formiga 
Só trabalha e não descansa

(Lima; Correia, 2006, p. 49).

Um segundo nível pode ser destacado no que toca à identificação dos interesses de classe fundamentais do operariado agrícola da regiáo. Com as dificuldades de sobrevivência econômica e a opressáo pelo regime ditatorial, na poética popular, surgem como vetores o contrariar da dinâmica do regime e o horizonte simbólico de construção de uma sociedade diferente, mais democrática e com direitos sociais e políticos. A ambição de transformar a sociedade e construir novas formas de sociabilidade humana surge no poema "O meu sonho":

Eu sonho com um mundo novo, isento de maldade

Em que os homens se estimem e dêem com amor

Um mundo de ventura e eterna felicidade

Donde p'ra todo o sempre seja banida a dor.

Um mundo em que haja paz em toda a terra

Em que o ódio e a dor jamais tenham guarida

Um mundo em que a semente da miserável guerra

Se mantenha p'ra sempre dos homens esquecida.

Eu sonho um mundo novo repleto de alegria

Donde desapareça o mal que nos consome

Um mundo em que se possa gozar a luz do dia

E onde jamais alguém possa morrer de fome

(VVAA, 1987, p. 59).

Sinteticamente, a poética cantada do operariado rural alentejano evidencia traços muito específicos de sua consciência/identidade de classe; náo só uma abordagem existencial muito forte sobre sua condição social, mas também a subvalorização do religioso e mesmo sua reconversão para a luta política secularizada e desligada do controle da Igreja; a construçáo mental e simbólica da terra como um utensílio a cultivar, e não como a raiz natural das relaçóes sociais de propriedade; a autoidentificaçáo como trabalhadores explorados e com interesses econômicos e políticos opostos aos dos grandes proprietários da terra; a produção de uma linguagem de classe. Todas essas dimensóes culturais não se espelharam táo somente no terreno da produção simbólica; com efeito, materializaram-se no real concreto e histórico, logo, assumiram uma dimensão política e social. 


\section{UMA SEGUNDA FACETA DA CULTURA POPULAR ALENTEJANA: REFLEXIVIDADE OPERÁRIA SOBRE SUA CONDIÇÃO DE CLASSE}

O segundo eixo de nossa pesquisa de terreno debruça-se sobre a subjetividade de três atores sociais pertencentes ao tempo e ao objeto empírico de nosso estudo. No fundo, interessou-nos, nesse eixo, resgatar e explanar as vozes de agentes sociais, de modo a que eles pudessem comentar suas vivências no decurso de processos sociais e históricos descritos anteriormente. Consequentemente, entendeu-se relevante enquadrar as biografias de operários agrícolas em torno de uma coordenada específica: o sentimento de solidariedade entre os trabalhadores'.

Por seu turno, o recurso às histórias de vida recriou, pela evocaçáo da experiência contada e vivida pelos agentes sociais, uma nova manta de representaçôes sociais e simbólicas. De fato, o método biográfico leva os agentes sociais a realizarem uma reflexáo própria sobre um conjunto de acontecimentos e fenômenos que vivenciaram.

Nas palavras de Machado Pais (200I, p. I07): "o que está em jogo no uso do método biográfico é a recuperaçáo de memórias narradas do ponto de vista de quem as evoca”, o que parece dar a entender que as histórias de vida trazem para o texto analítico a tessitura da subjetividade dos indivíduos. No fundo, a análise sociológica enriquece-se, aqui, por via da recolha, do tratamento e da interpretaçáo teórica do discurso dos agentes.

Fundamentalmente, não se trata de fazer do discurso dos agentes matéria científica acabada ou sequer potencialmente explicativa, a apenas necessitar de uma translação da linguagem do senso comum para o vocabulário científico. Na verdade, o retomar das palavras dos agentes cumpre, essencialmente, uma função de captação de camadas do tecido social, dificilmente apreensíveis por outros métodos e técnicas.

Basicamente, a enunciação das representaçóes individuais e coletivas náo cabe ao investigador per si, mas este deve ouvir, recolher e, finalmente, interpretar o universo simbólico, cognitivo e afetivo dos agentes sociais. Daí que seja extremamente fecunda a seguinte elucubração de José Machado Pais (200I, p. I07): “em jogo" no método biográfico "está também a possibilidade de tornar visível o que nem sempre é empiricamente detectável, precisamente as dimensóes invisíveis de um fenómeno".

Por conseguinte, mais do que retratar vidas humanas em sua globalidade, pretendeu-se que os agentes sociais entrevistados alavancassem domínios de experiência operária em um conjunto definido de temas diretamente conectados com a formação do operariado agrícola alentejano e com sua base de sustentação: a cultura popular assente em valores de solidariedade e de união coletiva.

\footnotetext{
4 Outros temas, como a relaçáo dos trabalhadores com os agrários e com o Partido Comunista Português, sem esquecer as condiçóes de vida, a repressão no período da ditadura de Salazar e a resistência a ela, bem como as vivências durante o período da Reforma Agrária e o balanço afetivo-simbólico desencadeado com seu final, foram abordados em nossa investigação. Por razóes de economia de espaço, mas também como forma de enfatizar o papel determinante - nunca exclusivo - da esfera cultural sobre a formação da classe trabalhadora, escolheu-se o tópico supramencionado da solidariedade entre os trabalhadores agrícolas alentejanos.
} 
Recolher o "sentimento do período histórico" (JAMES, 2004, p. 290) [itálicos colocados] contemplado foi o desígnio desta seçáo, em especial no que toca ao propósito de objetivar a consciência de classe de três operários agrícolas em sua concreção, em sua expressividade mais crua; em poucas palavras, transformar os relatos dos trabalhadores em testemunhos orais.

Como base de nosso trabalho, foi definido o papel da cultura operária na formação da consciência política e social dos trabalhadores agrícolas alentejanos. Relembrando esse tópico, deu-se, entấo, a palavra aos agentes entrevistados e foi tratado como eles apreendem a importância do coletivo e da solidariedade patentes nas redes de sociabilidade operárias.

CJ, operário agrícola com sessenta e oito anos de idade e proveniente da aldeia do Couço, concelho de Coruche, considera que nos trabalhadores alentejanos e ribatejanos da margem sul havia uma

consciência da solidariedade muito grande. A importância da solidariedade via-se, por exemplo, na que manifestávamos com os trabalhadores presos pelo regime. Naquele tempo afirmar os valores da democracia e da liberdade no contexto do regime ditatorial de Salazar era um enorme ato de coragem que só podia ser tomado coletivamente (CJ).

É interessante a forma como CJ aborda essa questáo. Em termos simples, para que os trabalhadores alentejanos pudessem afrontar um regime político que consideravam como obstáculo à concretização de seus interesses mais vastos e das necessidades mais prementes, só sua agregação grupal poderia funcionar como aríete contra o Estado Novo. Todavia, a unidade coletiva dos trabalhadores não bastava, segundo $\mathrm{CJ}$. Era preciso acrescentar-lhes

três formas de consciência: do mundo e do país em que viviam; da transformação social (mundo em constante mudança); do seu papel nesse processo de transformação. Isto tinha depois ligaçáo com o próprio conceito que o trabalhador alentejano tinha de posse da terra. Havia até um ditado onde se dizia, "a terra? Para que a quero eu a ter? Quando entro em casa até sacudo os pés!” (risos) (CJ).

Este "limpar a terra dos pés" conota uma noção de desprendimento em relação à propriedade individual e de despojamento corporal relativamente ao que não lhe é inerente. Até neste capítulo, o assalariado agrícola alentejano assume uma condição de desapossamento dos meios de produção; no caso, simbólicos. Porém, esse sentimento de comunidade repercute-se por vezes e refere o mesmo entrevistado, em certo "Sentimento de desconfiança de quem vem de fora, às vezes quase uma autarquia comunitária” (CJ).

Quer dizer, o fechamento da comunidade operária comunga de nossa asserção de que, naquela região do país, vivenciavam-se dois universos culturais e ideológicos. Redimensionando suas vivências quotidianas em um campo cultural e de sociabilidade próprio, o operariado agrícola 
alentejano secretava produtos simbólicos seus, em grande medida autônomos de influências de outras classes sociais.

Tomando o conceito de cultura em um domínio mais vasto, percebe-se, por conseguinte, como as redes de interaçáo, agrupamento coletivo e de sociabilidade interindividual dessas comunidades rurais operárias consubstanciavam-se como fortes indutores de disposiçóes morais, políticas, estéticas e significativas, claramente distintas das encontradas em seu exterior. A assunção dessas experiências de vida passava por um sentimento de

naturalidade com que tudo foi feito ali. Por exemplo, as reunióes faziam-se com um petisco e com um copo, mesmo sabendo que corríamos o risco de surgir a Guarda. Isto permitia disfarçar as reuniôes, mas também porque víamos a luta com alegria, e náo com desespero, pelo menos da parte dos trabalhadores mais conscientes. Essa vivência em comunidade (CJ).

Ela consumava toda uma rede de sociabilidades e uma plataforma de produçáo profusa de conteúdos culturais muito próprios, que se refletiam no viver coletivo e político dessa classe. E que classe era essa? A que classe pertenciam aqueles agentes? Explicitando, a que classe social aqueles agentes sociais assumiam pertencer?

Para GA, operário de Montemor-o-Novo com oitenta e um anos de idade,

isto aqui são operários agrícolas. É proletariado agrícola, não são camponeses como lá no Norte. E não é por uma mania, é por uma razão científica. $\mathrm{O}$ operário agrícola năo tem nada seu, não tem terra sua, só tem dois braços. Isto é um operário industrial ou agrícola para trabalhar. Ele não é camponês. Por isso, chamávamos operários agrícolas aos trabalhadores agrícolas. Já em 62 havia essa consciência sentida de que eram operários agrícolas. É um raciocínio, é uma consciência de classe como tem um operário, não é? Para ele o que interessa é o trabalho, não é a terra. Na Reforma Agrária, năo quisemos a terra para nada, ela era para trabalhar (GA).

Mais uma vez a insistência de que a terra não é uma propriedade ou uma posse a ser apropriada individualmente, mas um recurso a trabalhar coletivamente. Paralelamente, a noção arreigada, historicamente reproduzida e reapropriada, de que os trabalhadores agrícolas da regiáo eram, em sua esmagadora maioria, assalariados não deriva de uma mera constatação estatística. De fato, como apontaremos na seçáa subsequente, parece evidente o elevado peso numérico e populacional do operariado agrícola em todo o Alentejo. Contudo, uma certeza estatística e demográfica não é idêntica à subjetividade com que os agentes sociais apreendem sua vivência, localização e condição social. Assim, o desenvolvimento de uma linguagem de classe - ainda por cima, assumindo explicitamente a pertença a uma determinada classe social - cristaliza uma orientação simbólica e ideológica marcada e corporizada pelos operários da regiấo. 
Notadamente, eram operários que residiam, sociabilizavam, conviviam e trabalhavam em unidades territoriais relativamente endógenas, portanto, imunizadas culturalmente (e politicamente) das influências e dinâmicas das classes dominantes e das instituiçốes do poder fascista nos campos (a União Nacional, os Grêmios ou as Casas do Povo).

GA acrescenta ainda que essa vida comunitária dos operários agrícolas alentejanos não dispensava o canto coletivo:

Às vezes cantava-se, juntava-se muita gente. Aos domingos, dia que năo se trabalhava, juntavam-se aos 20, 30 de braço dado a cantar as cançōes que tínhamos na época. Havia cançóes de amor, de raparigas e tal, depois ia para outra rua e cantava-se outra sobre a terra e juntava-se muita gente. Nas ceifas, homens e mulheres cantavam. Aí cantava-se muito. A tirar cortiça assobiava-se. A esgalhar cantava-se, esgalhar é limpar o relevo. Nas mondas, que era antes da monda química, as mulheres e os homens cantavam ao desafio. A música animava o pessoal. Sem ânimo não havia luta possível (GA).

Essa extensáo da vida cultural a toda uma série de atividades produtivas cunha o viver operário em uma multitude de sentimentos e em uma gama de acontecimentos recreativos, sempre perpassados pela solidariedade e pela celebraçáo simbólica da coletividade em que se encontram.

Olha. Havia muitos convívios. Se passasses numa rua de uma aldeia, mesmo aqui na cidade de Beja, ias ver muita malta toda junta a cantar e a dançar. O pessoal lá do norte como tu às vezes tem aquela ideia de que nós alentejanos divertimo-nos pouco. Mas não. Divertir não é bem a palavra certa, mas que havia uma alegria na vida do dia a dia das pessoas havia. Essa alegria era motor de nossa fraternidade para as lutas. Também havia muita gente a ler em conjunto e sessōes de leitura. Lembro-me de ver um operário culto do Partido, que tinha a quarta classe, a ler o Até Amanhä, Camaradas, do Álvaro [Cunhal, nota colocada], para alguns operários que não eram do Partido. Esse homem sabia até partes de romances de cabeça e contava isso na rua. Era muito giro. Claro que, quando sentíamos a GNR a aproximar das ruas, o pessoal debandava e dispersava logo. Também tínhamos que ter cuidado com os bufos. Mas nas aldeias era difícil ser bufo, porque toda a gente conhecia-se, toda a gente comunicava entre si sempre que aparecia alguém de fora. As brincadeiras eram muito engraçadas na altura. As crianças brincavam sem brinquedos, a fazer de conta que tinham brinquedos. Ou entáo fazíamos uns brinquedos com bocados de arame que às vezes se catava nas ruas. Parecíamos os meninos dos Esteiros (risos). Depois os miúdos andavam a pedir, a correr pela cidade, eram moços ao abandono. Tinha coisas más. A gente sabia que tinha de ir trabalhar muito cedo, muitos logo aos cinco ou seis anos. Muitos nem à escola iam, e eram raros os que tinham mais do que a instruçáo primária. Mas eu tenho a ideia de que, apesar da miséria, essa vida de garoto descalço ajudou-nos a ser solidários desde meninos. $\mathrm{O}$ 
que um apanhava de comida num campo levava aos outros. Mesmo na escola havia separaçáo entre os meninos das várias classes. Levávamos quase uma vida de malteses, mas onde não havia traição entre nós. A traição da confiança era das atitudes mais graves e mais condenáveis que alguém poderia fazer $(\mathrm{HJ})$.

Assim fala HJ (setenta e seis anos) de Beja. HJ corrobora igualmente a tese da incomunicabilidade cultural e sociabilitária entre os operários agrícolas e os grandes senhores da terra. Oferece ainda um exemplo concreto da forma como (não) se relacionavam.

Com os latifundiários? Quase não falávamos, quando se falava. Era gente de grande insensibilidade. Por exemplo, o Dom Diogo em Ferreira do Alentejo. Não deixava no final da ordenha ou da apanha os trabalhadores aproximarem-se e alimentarem-se do que quer que fosse que sobrasse. Era de um desprezo para com a fome de quem lhe produzia a riqueza... Era um sujeito horrível. Outra situação que não gostava nada era quando alguns trabalhadores vinham com um chapéu pedir ao café Luiz da Rocha esmola. Era uma exceção, era gente medrosa. Ou então quando os trabalhadores saíam às arrecuas de falar com dom Diogo. Isso sim era degradante. Mas eu não os culpo. A malta era muito pobre, passava fome, e era natural que achassem que o senhor deveria ser benemérito. Aquela gente odiava os trabalhadores. Viam-nos como animais ou sei lá o quê $(\mathrm{HJ})$.

Comparando com o individualismo característico das últimas décadas, Honrado exalta a solidariedade coletiva manifestada pelo operariado agrícola no passado.

Era uma solidariedade, uma união como não se vê hoje. Dou-te um exemplo, trabalhadores que davam o conduto ou parte dele para o homem conseguir resistir no trabalho. Alguns andavam com uma pedra na bolsa para fazer de conta que não se passava fome. Sol a sol, fome, nem sei como aquela gente aguentava as ceifas. Ainda por cima trabalhava-se três a quatro meses por ano. $\mathrm{O}$ resto do ano era desemprego. Aqueles olhos cavados de fome metiam impressão. Se não fosse a união entre a malta não sei o que teria sido de nós. Eram outros tempos e era outro regime, mas era uma ajuda entre os trabalhadores que não há hoje. Era espontânea e que era comum à gente que nem era politizada $(\mathrm{HJ})$.

O sentimento de injustiça relativamente às condiçóes de vida existentes durante o regime ditatorial ajudou a fermentar um sentido coletivo de pertença de classe. Assim, a mobilizaçáo coletiva, mesmo no contexto da ditadura, assumia foros de maior facilidade em sua concretização.

Nos jogos de futebol, incentivava-se a participação da malta politizada ou do Partido no jogo em cada equipe. O objetivo era aproveitar aqueles laços de uniáo e ir mobili- 
zando os trabalhadores. No fundo, a malta, quando se sentia injustiçada, lutava mais facilmente $(\mathrm{HJ})$.

A mobilização política e social, que, em muitos casos, o Partido Comunista Português induziu junto ao operariado agrícola alentejano (e em outras franjas da classe trabalhadora portuguesa), demonstra que a movimentação de contingentes populacionais em torno de determinadas reivindicaçóes não é um puro e linear resultado da ação de um agente político (ou sindical) organicamente exterior à classe. $\mathrm{Na}$ realidade, a transversalidade de disposiçóes (e de predisposiçôes) com base em sentimentos de solidariedade, de desprendimento em relaçáo à propriedade privada da terra e no afrontamento/antagonismo (simbólico e ideológico) entre trabalhadores e grandes proprietários evidencia, em seu conjunto, que, sem determinados fatores de índole ideológica-cultural, a mobilizaçáo política não tem o alcance que seus resultados, à primeira vista, poderiam fazer crer.

\section{A FORMAÇÃO DA CLASSE TRABALHADORA ALENTEJANA (1926-1974)}

O último eixo de nosso trabalho de terreno repercute um caráter ligeiramente mais historiográfico e processual: a formação e o desenvolvimento das movimentaçóes sociais e políticas do operariado alentejano, entre o início da década de 1930 e 25 de abril de 1974.

De fato, a compilaçáo de elementos documentais (excertos de jornais e dados estatísticos) sofreu, nesta seção, um processo interpretativo, acentuando os traços fundamentais acerca da movimentação da classe operária alentejana.

A esse título, atente-se às lutas e às movimentaçóes coletivas do operariado agrícola contra o regime ditatorial do Estado Novo. Com efeito, o padrão das lutas operárias durante a ditadura fascista derivou, como já visto aqui, da matriz cultural da classe trabalhadora agrícola alentejana, bem como também da organização interna da estrutura fundiária.

Sucintamente, interligando território, recursos e relaçóes sociais, importa agora caracterizar a mancha classista no Alentejo. Desse modo, atente-se para o critério posse/propriedades da terra (principal meio e recurso social de produção) como o fator mais estruturante para a definiçáo das classes sociais da regiáo, antes de 1974. Com efeito, aliada a uma baixa taxa de urbanização na região, chega-se às vésperas da Revolução dos Cravos, com a seguinte distribuição das classes sociais:

A concentração da terra na virada para a década de 1970 era nítida. A classe dominante nos campos - uma parte ínfima da populaçáo, pouco mais de $2 \%$ - detinha mais de dois terços das terras; para não falar que os cerca de $30 \%$ de terras restantes nas mãos dos pequenos agricultores eram ou exploraçôes com funçôes de mera subsistência/sobrevivência familiar ou propriedades com solos pouco férteis. Por outro lado, os assalariados agrícolas - que representavam pouco mais de $80 \%$ da populaçáo - encontravam-se destituídos do recurso em que eles trabalhavam quotidianamente: a terra. E isso quando tinham emprego. 
Tabela 1. Classes sociais nos campos alentejanos.

\begin{tabular}{lccc}
\hline \multicolumn{1}{c}{ Classes sociais } & Latifundiários & $\begin{array}{c}\text { Pequenos } \\
\text { agricultores }\end{array}$ & $\begin{array}{c}\text { Assalariados } \\
\text { agrícolas }\end{array}$ \\
\hline Percentagem da população ativa & $2,3 \%$ & $14 \%$ & $83,6 \%$ \\
Área agrícola & $2.200 .000 \mathrm{ha}$ & $1.000 .000 \mathrm{ha}$ & - \\
Percentagem do total de terras & $68,7 \%$ & $31,2 \%$ & - \\
\hline
\end{tabular}

Fonte: dados do INE (2008 - explorações agrícolas; 1970 - inquérito à população).

Quando da Revoluçáo que iria instaurar o regime democrático, estima-se que havia cerca de quatorze mil desempregados agrícolas (PIÇARRA, 2004, p. 2I2). Paralelamente, a situaçáo econômica do operariado agrícola da região é, no mínimo, precária. Para além do trabalho de sol a sol, que iria pintar a regiáo desde tempos imemoriais até 1962, e do desemprego, atenta-se que, apenas para exemplificar, entre I960 e 1962, as jornas eram de 24 a 30 (quinze cêntimos de euro, no máximo) para os homens e de $\mathrm{I} 3$ a $16 \$$ (oito cêntimos de euro por dia) para as mulheres (GERVÁsio, 2004, p. I82).

Esse quadro de vulnerabilidade socioeconômica do operariado irmanava e complementavase com um clima de brutal repressão, tendo em vista que às dificuldades de subsistência dos trabalhadores da regiáo adicionava-se constantemente um espírito combativo de revolta, com resultados óbvios na resposta violenta das autoridades fascistas.

O regime não apenas punia com a violência física as manifestaçóes de trabalhadores, mas também com prisão, tortura e mesmo, em alguns casos, com a morte.

No que concerne à atividade econômica, por meio de uma leitura atenta do Projeto do II Plano de Fomento (1958) para a agricultura, não se encontra sequer uma linha sobre a melhoria das condiçóes de vida das populaçóes trabalhadoras da regiáo. Todo o Plano, alegadamente destinado a fomentar o desenvolvimento econômico do país, náo contempla nunca a melhoria dos salários na regiáo, o combate ao desemprego, a introdução de mecanismos legais traduzidos em termos de contratualidade laboral, a modificaçáo dos horários de trabalho, etc. Em todo esse texto oficial do regime, apenas encontram-se tópicos relacionados com "hidráulica agrícola", "povoamento florestal" e "reorganizaçáo agrária" (VvAA, 1958).

Mesmo o último ponto - reorganizaçáo agrária - apenas foca a questáo da melhor forma de reconfigurar a estrutura da propriedade de forma a tornar o latifúndio mais rentável do ponto de vista capitalista.

Por conseguinte, a contestação do regime do Estado Novo surge como uma extensão dessa dupla dinâmica assente na esfera simbólico-ideológica - a cultura popular da regiáo - e nas relaçôes de propriedade preponderantes no latifúndio.

A consolidação institucional do regime político do Estado Novo não apenas teve consequências quanto à própria sobrevivência de uma forma fundiária arcaica: o latifúndio, essa consolidação institucional do regime fascista - conseguida com o desbaratar violento de toda a oposição popular, desde o "reviralho" até a ilegalidade de todos os partidos e a repressão brutal 
da greve geral de 18 de março de $1934^{5}$ - teve também reflexos na própria dinâmica da classe trabalhadora alentejana.

A primeira propriedade a registar consubstancia-se na necessidade que a classe operária agrícola da regiáo teve em adotar formas de luta que exigissem uma clara consciência política/ social da longa duração dos enfrentamentos de classe. Em outras palavras, a "fascização" da vida nacional - assente na proliferação de organizaçóes estatais e paraestatais, como Casas do Povo, o Movimento Nacional Feminino, a Legião Portuguesa, a Mocidade Portuguesa, os Sindicatos Nacionais, a FNAT, etc. que denotam uma clara sustentação e robustez orgânica interna do regime, pelo menos até sua primeira grande crise, com o fim da Segunda Guerra Mundial e a derrota das experiências fascistas por toda a Europa -, o apoio internacional das potências autoritárias (Itália, Alemanha, Espanha franquista, etc.) e o eficaz e seletivamente orientado recurso à violência física e à censória contra seus adversários políticos forneciam uma estabilidade ao regime fascista de Salazar, em que as lutas de afrontamento aberto estariam fadadas ao insucesso.

Assim, face ao poder do Estado fascista e de uma das classes hegemônicas do bloco no poder à época, a luta operária nos campos alentejanos assumiu novas formas, relativamente ao que tinha ocorrido na Primeira República: iniciativas influenciadas pelo anarcossindicalismo, assentes na ação direta. Ainda mais relevante, iria crescer a consciência de que a movimentaçáo coletiva dessa classe teria de ser orientada para um longo processo de acumulaçáo de forças.

Essa noção da movimentação coletiva concretizar-se-ia, de um lado, por intermédio de uma persistente luta econômica e reivindicativa, de modo a colmatar as gritantes necessidades básicas dos trabalhadores alentejanos e, de outro lado, pela construção de uma classe social com elevado grau de politização e de consciencializaçáo acerca de sua situaçáo como assalariados agrícolas economicamente explorados pelo latifúndio e politicamente oprimidos pelo regime.

Essa dimensão de longa duraçáo é bem expressa nas palavras de Américo Leal (2005, p. 28):

após muitas lutas contra o trabalho de sol a sol e pela redução do horário de trabalho em certas actividades, como na cava das vinhas e noutros trabalhos pontuais, foi a partir de 1960 que os trabalhadores agrícolas do Alentejo passaram a ter no Verão duas horas para o almoço e meia hora para a merenda, o que, mesmo assim, os obrigava a trabalhar II e I2 horas por dia. Os salários, embora sempre dependentes da luta dos trabalhadores em cada regiáo, e por vezes em cada herdade, eram, em I940, de 8 a Io escudos por dia para os homens e de 2 a 3 escudos para as mulheres, passando, em 1960, na Herdade da Palma e devido a constantes aç̧ôes reivindicativas, para is escudos para os homens e 7 escudos para as mulheres [itálicos colocados].

\footnotetext{
5 O regime realizou "um total de 696 presos" (PATriarCa, 2000, p. 458) no rescaldo dessa iniciativa de luta operária,
} constituindo o "esfrangalhar dos núcleos de resistência à organização corporativa" (Idem, p. 490). 
Repare-se que o aumento salarial referido pelo autor demorou cerca de vinte anos para ser conseguido. Daí se depreende o carácter de longa duração das lutas operárias no Alentejo, decorrente da própria natureza do regime e da estrutura fundiária existente.

A mutação no tipo de lutas operárias na regiáo iria obedecer a dois fundamentos principais:

1) desenvolver no plano político os laços de solidariedade e de fraternidade já existentes no nível das sociabilidades culturais, o que significava adotar lutas reivindicativas em torno de objetivos concretos e de satisfação imediata dos trabalhadores agrícolas (salários, horários de trabalho, períodos de descanso, etc.);

2) procurar agregar à luta descoordenada em cada herdade essas lutas parciais por vila ou aldeia, apostando-se, para isso, na intervençáo reivindicativa nas praças de jorna existentes em cada unidade administrativa territorial.

Nas décadas de 1940 e 1950, a par das mobilizaçôes em torno de reivindicaçóes de carácter econômico, começaram a acrescenta-se camadas de componente política às mobilizações operárias. Sobretudo na década de 1950, não apenas se recorre com maior frequência à greve como forma de luta, como o afrontamento com o regime se torna mais violento. Estando ausente qualquer forma de legitimaçáo ideológica ou de caráter normativo para barrar as mobilizaçóes operárias, só uma repressão mais implacável poderia obstar à crescente magnitude da organização coletiva dos assalariados agrícolas alentejanos. Aliás, a repressão por si só é insuficiente para fazer retroceder um movimento popular ascendente, sobretudo se não se consegue destruir as bases produtoras de seu viver social: no caso do operariado agrícola alentejano, sua base cultural, sua posiçáo nas relaçôes sociais de produção da propriedade latifundiária, a não destruição da organizaçáo política que mais de perto operava junto dessa classe.

Os casos de assassinato de várias figuras políticas alentejanas (contam-se apenas os casos antes de I958) pelas forças policiais (GNR e PIDE) do regime, como Germano Vidigal - assassinado em junho de 1945, à pancada, no posto da GNR -, António José Patoleia - morto, em 1947, na sede da polícia política de Vila Viçosa -, Alfredo Lima - morto a tiro pela GNR da localidade, em I950 - e Catarina Eufémia - assassinada à queima-roupa em I9 de maio de 1954, na aldeia de Baleizáo -, evidenciam como a violência, no caso da luta operária alentejana contra o regime e por melhores condiçóes de vida, náo é suficiente para desorganizar uma classe que conta com um nível de estruturaçáo interna muito forte, no que concerne tanto à solidariedade entre os operários em luta como à sua disposição para lutar e enfrentar as forças policiais, com objetivos políticos muito precisos.

$\mathrm{Na}$ década de 1960 ocorreu um dos acontecimentos mais importantes e mais marcantes de centenas de anos de luta dos assalariados da regiáo: a luta pela conquista das oito horas diárias de trabalho. O fim do secular trabalho de sol a sol seria possível em um contexto de desagregaçáo interna do regime (agravada pelo início da Guerra Colonial, em I96I, e pelas lutas estudantis de 1962) e de crescente capacidade organizativa da classe operária agrícola alentejana.

A conquista das oito horas diárias de trabalho foi precedida de centenas e centenas de açóes de protesto e reivindicativas ao longo, pelo menos, das duas décadas anteriores. Por outro lado, 
em um período mais curto, a mobilização operária de abril e maio de 1962 rematou todo um longo processo de "pequenas reuniôes de trabalhadores para discutir o Primeiro de Maio e as 8 horas de trabalho por dia" (GERvásio, I996, p. 20).

A proliferação de reunióes - quase todas clandestinas - pelos campos alentejanos foi acompanhada da definição pela base dos trabalhadores agrícolas de um conjunto de reivindicaçóes que seriam publicadas no jornal do PCP, dedicado para aquela classe - O Camponês -, em sua edição de junho daquele ano:

As nossas reivindicaçóes económicas mais imediatas e pelas quais devemos lutar são: $\mathrm{I}^{\mathrm{o}}$ - Garantia de trabalho;

$2^{\circ}$ - Salários mínimos de 30 escudos para homens e 20 escudos para mulheres. Que ninguém trabalhe por menos destes salários;

$3^{\text {o }}$ - Jornada de 8 horas. Que ninguém trabalhe de sol a sol (VvaA, jun. I962, p. I).

Esse era um caderno reivindicativo que já se podia encontrar desde I954 (VVAA, mai. I954, p. I). Assim, aproveitando a comemoraçáo do Io ${ }^{\circ}$ de maio, operários do Alentejo e da margem sul do Ribatejo levariam a cabo uma ação de luta deveras eficaz e criativa. Na prática, dezenas de milhares de operários agrícolas, nas primeiras semanas de maio, apenas trabalharam durante oito horas, tirando uma hora para o almoço.

Como iria registar António Gervásio, principal dirigente das lutas operárias de 1962 no Alentejo:

A conquista das 8 horas pelos operários agrícolas do Sul constitui uma importantíssima vitória política dos trabalhadores do campo. Mais de 250 mil trabalhadores têm participado nesta luta através da greve, de concentraçóes, de levantamentos de ranchos, de choques com as forças repressivas, etc. A luta não tem sido fácil. Muitos trabalhadores têm sido presos e outros obrigados a fugirem das suas terras. Se os agrários não têm resistido mais é porque a luta tomou uma tal envergadura que assustou os fascistas. O mês de maio de 1962 ficará sendo uma data histórica no movimento dos operários agrícolas. As 8 horas são uma das reivindicaçôes mais sentidas dos assalariados agrícolas do Sul (VvaA, jun. I962, p. 45).

Assim se dava uma nevrálgica machadada na forma de propriedade do latifúndio em decadência. Náo se pense, todavia, que essa grande onda de mobilizaçáo operária foi alcançada pacificamente. Depois do assassinato de Adelino dos Santos, morto a tiro em frente à Câmara Municipal de Montemor, em 1958, António Adângio seria assassinado a tiro nas ruas de Aljustrel, em 28 de abril de 1962, precisamente no momento em que a onda de duzentos e cinquenta mil operários agrícolas começava a se erguer. Também por aqui se percebe o grau de decomposiçáo 
do regime e sua incapacidade de destruir as condiçôes - sociais, econômicas, culturais e políticas - de germinação da escalada de mobilizaçáo do operariado agrícola alentejano.

Dessa jornada de 1962 retiremos duas relevantes notas de balanço. Uma primeira, a de que a jornada diária de oito horas foi conseguida por intermédio da ação política dos trabalhadores agrícolas, e não se tratou de uma benesse qualquer do Estado Novo e das classes dirigentes de entấo. Se as oito horas nunca vieram a ser regulamentadas juridicamente, sua prática efetiva foi concretizada na generalidade das grandes herdades alentejanas.

Um primeiro sinal da possibilidade da mudança das estruturas sociais, por parte da açáo de um sujeito social coletivo, pode ser evidenciado nesse ponto específico. Uma segunda nota prende-se com o "entrelaçamento da luta política com a luta económica" (VvAA, jun. 1962, p. 64). Com a escolha do $\mathrm{I}^{\mathrm{o}}$. de maio como abertura das hostilidades, o operariado agrícola da regiâo deu um salto qualitativo em sua própria percepçáo como sujeito social. De um sujeito vocacionado para lutar por objetivos imediatos - o que também aconteceu nas jornadas de 1962 -, o operariado alentejano assumiu-se como um sujeito político capaz de se mobilizar por toda a planície alentejana (e ribatejana), pelo que considerava serem suas aspiraçóes mais profundas, conseguindo atingir conquistas que representavam duros e rudes golpes no poder do latifúndio e do próprio regime no Alentejo.

Como referiu António Gervásio, "os trabalhadores ligaram a comemoração do Io de maio com a luta pela conquista das 8 horas, com a luta por um salário certo de 40 escudos para as ceifas e de 30 escudos para os serviços dos arrozais" (VvaA, jun. I962, p. 64).

O cruzamento das duas modalidades de mobilização política e social descreve um grau de organização e de consciencializaçáo muito mais agudo por parte do operariado agrícola, tendo forte repercussão nas duas décadas seguintes.

Nos doze anos seguintes até a Revoluçáo de Abril, pudemos constatar que as lutas reivindicativas, greves e concentraçôes continuaram, solidificando a unidade interna dessa classe social. Ao mesmo tempo, a contestaçáo da Guerra Colonial politizou ainda mais o próprio operariado agrícola alentejano.

\section{CONCLUSÃO}

Nossa hipótese central de que a cultura popular se sustentou nos campos alentejanos como o solo (cultural) de onde brotaram as sementes da revolta dos assalariados agrícolas denuncia índices de corroboração empírica. Desde os domínios substantivos da poética cantada analisados, até aos registos orais e biográficos de operários entrevistados, em que pontificavam concepçóes do mundo social autocentrados na solidariedade entre os membros da classe trabalhadora local, a mobilização da classe trabalhadora alentejana seria impossível sem índices de autoidentificação de classe, de laços de companheirismo e de uma concepção do mundo social antagônica relativamente à das classes dominantes nos campos. Por outro lado, tal como uma semente, a classe trabalhadora alentejana pôde alcandorar-se à posiçáo de uma classe social capaz de competir 
com as classes dominantes da região pelo controle da produção da vida social e econômica no Alentejo, na medida em que tinha:

a) como solo para germinação, uma prolífica produção cultural autocentrada em sua vida sociabilitária local e em seu próprio caráter de autoprodução cultural, portanto, altamente desconectado da produção cultural e ideológica exterior às suas comunidades e à sua regiáo;

b) como agente semeador de revoltas e de mobilizaçóes coletivas, o Partido Comunista Português, que, por um lado, adequou seu conteúdo programático às aspiraçôes quotidianas de emprego, salários, horários de trabalho e de visão (ou mundivisão) do operariado agrícola e, por outro lado, ajudou a forjar uma cultura regional (algo único no país), que projetou seu universo cultural precedente a um nível diretamente mais político: a um mais aberto confronto com a ditadura de Salazar e pela posterior tentativa de construção de uma nova ordem social e econômica. Constituiu-se, assim, uma cultura política, um tabuleiro axiológico operacionalizado em termos de açôes políticas e reivindicativas. Por conseguinte, mesmo as práticas políticas não se descartam de variáveis de índole cultural e significativa em sua própria constituição interna;

c) como condiçóes externas à mão humana, um regime político alicerçado na repressão impiedosa das revoltas operárias e, posteriormente, um contexto histórico de disrupção de um regime opressor e de uma estrutura agrária arcaica que fermentaram um terreno mais favorável à construção de um forte sentimento de injustiça, importante instrumento de mobilização coletiva naquele contexto.

Com efeito, a cultura assumiu, do ponto de vista sociológico, um posicionamento deveras interessante. No momento histórico - anos 1930 - em que o Estado Novo reprimiu e desbaratou toda a oposição operária do período da Primeira República, a cultura popular alentejana e toda a rede de sociabilidades que a sustentava surtiram efeitos de reserva axiológica, simbólica e ideológica de valores e sentimentos de solidariedade, de autoidentificação de classe e de sentimento de injustiça face à situação vulnerável em que viviam os operários agrícolas de então. Em outro contexto, dos anos 1940 até a Revolução de I974, essa plataforma predominantemente simbólica fundiu-se politicamente com várias das propostas políticas que foram chegando à regiáo. Nesse contexto, o saber fazer performativo da classe trabalhadora alentejana alimentava a reivindicaçáo social e política, e, do mesmo modo, esta última fortalecia os laços sociais existentes no nível dos quadros de interação quotidianos.

\section{REFERÊNCIAS BIBLIOGRÁFICAS}

Almeida, João Ferreira de. Classes sociais nos campos. Oeiras: Celta, 1999.

Bourdieu, Pierre. Le sens pratique. Paris: Minuit, 1980. 

. Esboço de uma teoria da prática. Oeiras: Celta, 2002.

Burawoy, Michael. Manufacturing consent. Chicago: University of Chicago Press, 1982.

Caria, Telmo. A construçáo etnográfica do conhecimento em Ciências Sociais. In: CARIA, Telmo (Org.). Experiência etnográfica em Ciências Sociais. Porto: Afrontamento, 2002. pp. 9-20.

Costa, António Firmino da. A pesquisa de terreno em sociologia. In: Pinto, José Madureira; Silva, Augusto Santos (Org.). Metodologia das Ciências Sociais. 11. ed. Porto: Ediçōes Afrontamento, 2001. pp. 129-148.

Denzin, Norman. Introduction. In: Denzin, Norman; Lincoln, Yvonna (Org.). The landscape of qualitative research. Thousand Oaks: Sage, 1998. pp. 1-34.

Geertz, Cliford. O saber local. Novos ensaios em Antropologia Interpretativa. Petrópolis: Vozes, 1999.

Gervásio, António. Lutas de massas em abril e maio de 1962 no Sul do país. Lisboa: Edições Avante, 1996.

- A luta do proletariado agrícola: de sol a sol até à Reforma Agrária. In: Murteira, António (Org.). Uma revolução na revolução: reforma agrária no Sul de Portugal. Montemor-o-Novo: Câmara Municipal de Montemor-o-Novo, 2004. pp. 181-187.

Glaser, Barney; Strauss, Anselm. The discovery of grounded theory: strategies for qualitative research. New York: Aldine de Gruyter, 1997.

INE. Instituto Nacional De Estatística. Superfície agrícola utilizada (ha) por localização geográfica (NuTs - 2002) e classes de superfície agrícola utilizada. In: INE. Inquérito às estruturas das exploraçôes agricolas. Lisboa: INE, 2008.

JAMES, David. Contos narrados nas fronteiras: a história de Dońa Maria, história oral e questōes de género. In: Batalha, Cláudio; Silva, Fernando Teixeira da; Fortes, Alexandre (Org.). Culturas de classe. Campinas: Editora da Unicamp, 2004. pp. 287-314.

Kirk, Neville. Cultura: costume, comercializaçáo e classe. In: Batalha, Cláudio; Silva, Fernando Teixeira da; Fortes, Alexandre (Org.). Culturas de classe. Campinas: Editora da Unicamp, 2004. pp. 49-70.

LeAL, Américo. O rosto da reforma agrária. Lisboa: Ediçóes Avante, 2005.

Lima, Paulo; Correia, Susana (Org.). Vida, fome e morte nos campos de Beja durante o salazarismo. Beja: Câmara Municipal de Beja - Arquivo de História Oral, 2006.

Navarro, António Modesto. Memória alentejana - resistência e reforma agrária em Benavila e Campo Maior. Lisboa: Ediçôes Avante, 2002. 
PAIs, José Machado. Introdução. In: PAIs, José Machado (Org.). Traços e riscos de vida. Porto: Âmbar, 2000. pp. 5-15.

Ganchos, tachos e biscates. Porto: Âmbar, 2001.

Patriarca, Fátima. Os sindicatos contra Salazar: a revolta do 18 de janeiro de 1934. Lisboa: Imprensa de Ciências Sociais, 2000.

PiçARra, Constantino. O movimento social dos assalariados agrícolas do distrito de Beja: do 25 de abril às primeiras ocupaçóes. In: Murteira, António (Org.). Uma revolução na revolução: reforma agrária no Sul de Portugal. Porto e Montemor-o-Novo: Campo das Letras e Câmara Municipal de Montemor-o-Novo, 2004. pp. 201-214.

Pinto, José Madureira. Estruturas sociais e práticas simbólico-ideológicas nos campos. Porto: Edições Afrontamento, 1985.

Pinto, José Madureira; Almeida, João Ferreira de. A investigação nas Ciências Sociais. Lisboa: Presença, 1995.

SEALE, Clive. The quality of qualitative research. Thousand Oaks: Sage, 2000.

SiLva, Manuel Carlos. Resistir e adaptar-se: constrangimentos e estratégias camponesas no noroeste de Portugal. Porto: Ediçóes Afrontamento, 1998.

Thompson, Edward. The formation of the English working class. London: Penguin, 1991.

VvaA. Grandes vitórias dos camponeses. O Camponês, ano VI, n. 44, p. 1, maio 1954.

. Boletim dos Serviços Industriais. Lisboa: Governo da República Portuguesa, 1958.

- Magnífica vitória dos operários agrícolas! Mais de 250 mil trabalhadores do Sul conquistaram as oito horas! O Camponês, n. 94, p. 1, junho 1962.

_. Poetas populares do concelho de Beja. Beja: Câmara Municipal de Beja, 1987.

. Cancioneiro de Serpa. Serpa: Câmara Municipal de Serpa, 1994.

. Memórias alentejanas: recolha de património oral. Moura: Escola Secundária de Moura, 2001. 